\title{
R Research Square \\ Determination and Statistical Analysis of Atmospheric Deposition of Heavy Metals in Kosovo. A Moss Survey
}

\author{
Flamur Sopaj \\ University of Prishtina \\ Trajče Stafilov \\ Ss Cyril and Methodius University \\ Krste Tašev \\ State phytosanitary laboratory \\ Robert Šajn \\ Geological survey of Slovenia \\ Musaj Paçarizi ( $\square$ musaj.pacarizi@uni-pr.edu ) \\ University of Prishtina https://orcid.org/0000-0002-1097-6619
}

\section{Research Article}

Keywords: Determination, statistical analysis, atmospheric deposition, heavy metals in Kosovo, moss survey, High concentrations, Pollution

Posted Date: August 26th, 2021

DOI: https://doi.org/10.21203/rs.3.rs-839800/v1

License: @ (1) This work is licensed under a Creative Commons Attribution 4.0 International License. Read Full License 


\section{Abstract}

Atmospheric deposition of heavy metals on the territory of Kosovo was studied using the already widely used technique of mosses as biomonitors. This is a very convenient method as it uses natural samples, and thus avoids many difficulties associated with man-made samplers. Nine heavy metals ( $\mathrm{Al}, \mathrm{Cd}, \mathrm{Cr}, \mathrm{Cu}, \mathrm{Fe}, \mathrm{Mn}, \mathrm{Ni}, \mathrm{Pb}$, and $\mathrm{Zn}$ ) were determined in 45 moss samples. Statistical analysis was performed to better present and explain the data. High concentrations of $\mathrm{Pb}, \mathrm{Zn}, \mathrm{Cd}$, and $\mathrm{Ni}$ were found near industrial sites and near more densely populated areas. Principal component analysis (PCA) identified more polluted sites such as Zveqan, Stanterg, Prapashticë, Siboc, and Lupç. It was also found that $\mathrm{Pb}, \mathrm{Zn}, \mathrm{Cd}, \mathrm{Cr}$, and $\mathrm{Ni}$ are the heavy metals that affect these polluted sites the most. The contamination factor (CF) and the polluted load index (PLI) were calculated. CF showed that only $\mathrm{Mn}, \mathrm{Cu}$, and $\mathrm{Zn}$, had no or almost no contamination no contamination levels over the range of moss samples, while $\mathrm{Cd}$ and particularly $\mathrm{Pb}$ gave extremely high values for $\mathrm{CF}$, indicating extreme contamination levels. Pollution load index also showed that only a few samples are slightly polluted, while most of the samples shown considerable and very high levels of pollution.

\section{Introduction}

Industrialization and development as necessary as they are, bring difficulties along. One of the worst consequences of industrialisation is the production of a lot of waste materials, which very frequently are harmful to the environment. Chemical pollutants generated from many industrial processes and other human activities are spread in waters, soil, and air, depending on their chemical-physical properties and the nature of the industry. Air pollution is a very serious issue and it has been reported continuously worldwide (Webb et al. 1992; Rocher et al. 2004; Soltanali et al. 2008; Silva et al. 2014; Li et al. 2017; Zhu et al. 2018; Ribeiro et al. 2019; McDonnell et al. 2020). Of course, Kosovo makes no exception regarding air pollution (Arditsoglou and Samara 2005; Kabashi et al. 2011; Zeneli et al. 2011).

Among air pollutants heavy metals are very common in every inhabited area, and also in not inhabited remote ones (Kord et al. 2010; Thöni et al. 2011; Vianna et al. 2011; Silva et al. 2014; Abuduwailil et al. 2015). They can harm human health in various ways once entering the organism (Järup 2003; Kampa and Castanas 2008; Kelly and Fussell 2011). Heavy metals can be inhaled with air (Järup 2003; MacNee and Donaldson 2003) or ingested with food, such as vegetables which have been exposed to polluted air or water during their development (Pandey and Sharma 2002; Khan et al. 2015; Shahid et al. 2017). Adverse effects have also been reported on plants and animals (Pandey and Sharma 2002; Reis et al. 2010; Khan et al. 2015). Therefore it is necessary to continuously measure the levels of heavy metals in air, so that appropriate actions can be initiated when they are beyond tolerated values.

Heavy metals are introduced into the atmosphere through various ways. Globally, they can rise into atmosphere from wind-blown dust, aerosols formed at sea surface, forest fires, volcanoes, and from biological processes such as methylation (Duce et al. 1975; Lantzy and Mackenzie 1979; Thayer and Brinckman 1982; Nriagu 1989). Anthropogenic origin of metals in the atmosphere is also significant and has had a continuous impact on living organisms. Metal production involves several sub-processes; such as digging, transport and crushing of the minerals, grinding, and concentration processes which are followed by extraction methods of metals from ores. During each stage dust and gasses can be released into the atmosphere. Thus, many 
reports have emerged indicating that mining and ore processing industry contributes to the atmospheric pollution with heavy metals (Lantzy and Mackenzie 1979; Walsh et al. 1979; Thayer and Brinckman 1982; Romo-Kröger et al. 1994; Mansha et al. 2012). Other sources of anthropogenic pollution are traffic, waste incineration, oil, fuel, and coal combustion (Trindade et al. 1981; Pacyna et al. 2007; Xia and Gao 2011; Suvarapu and Baek 2017).

The monitoring of metals atmospheric deposition, traditionally is performed by collectors which are spread throughout the area which is intended to be monitored. Despite the advantages this approach has, there are also drawbacks to be considered. Collectors have to be built, transported and maintained. This makes it complicated to be operated and expensive in comparison to some naturally grounded methods, such as moss survey (Schröder and Nickel 2019). Mosses grow naturally and it is easier to cover more area with higher density of sampling points with less cost (Harmens et al. 2010). They are currently widely used in monitoring of atmospheric heavy metals deposition because of their characteristic structure. Their cuticle being very thin, enables good permeability towards atmospheric gaseous, metals, water, and other chemical species along with it (Roberts et al. 2012; Mahapatra et al. 2019). The absence of real roots largely restricts the nutrients absorption to substrates they grow on (Mahapatra et al. 2019). They also contain a variety of organic molecules, which can act as complexing agents and ion exchange sites that can retain metals in the plant tissues (Wells and Brown 1990; Azuma et al. 2000; Klavina et al. 2015). These facts have made mosses a very suitable mean for air pollution investigation (Steinnes et al. 1994; Zechmeister 1998; Rühling and Tyler 2004; Harmens et al. 2010; Qarri et al. 2014; Barandovski et al. 2015; Macedo-Miranda et al. 2016; Lazo et al. 2018; Stafilov et al. 2018; Schröder and Nickel 2019).

This work aims to estimate the atmospheric deposition of most commonly expected heavy metals in Kosovo using mosses as bioindicators. It also intends to find patterns of the data distribution in order to locate the main sources of pollution through statistical analysis. The moss collection in Kosovo for the purpose of heavy metals atmospheric deposition analysis was first performed in 2010 (Maxhuni et al. 2016). Nine metals were investigated, namely: $\mathrm{Cd}, \mathrm{Cr}, \mathrm{Cu}, \mathrm{Fe}, \mathrm{Hg}, \mathrm{Ni}, \mathrm{Mn}, \mathrm{Pb}$, and $\mathrm{Zn}$, in 25 sampling points. It was found that the concentrations of metals, reached pollution levels with variation throughout the area studied. In this survey 45 samples were collected over the whole territory of Kosovo, evenly spread to the possible maximum allowed by moss presence. The concentration of $\mathrm{Al}, \mathrm{Cd}, \mathrm{Cr}, \mathrm{Cu}, \mathrm{Fe}, \mathrm{Mn}, \mathrm{Ni}, \mathrm{Pb}$, and $\mathrm{Zn}$, as more commonly expected heavy metals were determined in moss samples. The data obtained were processed by statistical analysis in order to identify polluted sites and pollution sources as well as to estimate the level of contamination.

\section{Materials And Methods}

\section{Study area}

Kosovo is situated in the centre of Balkan Peninsula with geographical coordinates between longitudes $41^{\circ}$ $50^{\prime} 58^{\prime \prime}$ and $43^{\circ} 15^{\prime} 42^{\prime \prime}$ and between the latitudes $20^{\circ} 01^{\prime} 30^{\prime \prime}$ and $21^{\circ} 48^{\prime} 02^{\prime \prime}$. It has a surface area of 10,900 $\mathrm{km}^{2}$ with an average altitude of about $800 \mathrm{~m}$ above sea level. It is characterized by a complex geologic setting and high mineral activity of $\mathrm{Pb}-\mathrm{Zn}, \mathrm{Cu}, \mathrm{Ni}$, and $\mathrm{Cr}$ throughout the territory. The total estimated land is at $858,063 \mathrm{ha}$, and about $63.3 \%$ is agricultural land area, and $35 \%$ is forest area. The geology of Kosovo is complex, with formations created at different intervals of geological timeline (Fig. 1). Metamorphic, flysch, 
carbonate rocks and clastic sediments appear to cover most of the area. Then, there are deluvial/proluvial sediments mostly in the west, south and to the east of the territory, magmatic rocks mostly are found in the north and the east and magmatic rocks mostly in the north and north/east. There are also alluvial sediments which lie along the river basins, such as Drin, Sitnica and Morava rivers.

\section{Sampling}

Moss samples were collected during the dry season of summer, August to September. The procedure of sampling was in accordance with Monitoring Manual of "International Cooperative Programme on Effects of Air Pollution on Natural Vegetation and Crops, 2020. Three types of mosses were collected: Homalothecium sericeum (Hedw.) Schimp. 1851, Hypnum cupressiforme Hedwig. 1801, and Pseudoscleropodium purum (Hedw.) M.Fleisch. Three to ten (mostly over five) samples were collected at each sampling site, in an area of $(50 \times 50) \mathrm{m}$. The collected mosses were put in paper bags of $1 \mathrm{~L}$ which were stored for $5-7$ days at ambient temperature $\left(20-25^{\circ} \mathrm{C}\right)$ prior to cleaning. Moss samples were taken at least $100 \mathrm{~m}$ away from small roads and over $300 \mathrm{~m}$ away from main roads, villages and industries. All samples were collected from ground soil avoiding rocks, and only sometimes from rotten branches or tree trunks, in open fields with low shrubs or without shrubs. In case of forest areas, open gaps of at least $10 \mathrm{~m}$ diameter were chosen for mosses sampling and at least a $3 \mathrm{~m}$ distance from the nearest tree canopy drip was always respected.

\section{Digestion}

Interfering materials such as other herbs, leaves, twigs, and vegetation parts were carefully removed to leave a clean moss mass. After this mosses were grinded by hand using gloves and dried at $40^{\circ} \mathrm{C}$ for $48 \mathrm{~h}$. Samples were digested in a microwave system by the wet digestion method. $0.5 \mathrm{~g}$ of sample were put in the Teflon tube, where $7 \mathrm{ml}$ of nitric acid and $2.5 \mathrm{ml}$ of hydrogen peroxide were added. The mixture was left to react for 10 minutes in order to give some time reactions to take place and some gases to release, so that less pressure would develop in the Teflon tube during microwave digestion. Then Teflon tubes were put in the microwave system with a program: $5 \mathrm{~min}$ up to $170^{\circ} \mathrm{C}$, hold time of $10 \mathrm{~min}$ at $170^{\circ} \mathrm{C}, 1 \mathrm{~min}$ up to $200^{\circ} \mathrm{C}$, hold time of 15 min at $200^{\circ} \mathrm{C}, 1 \mathrm{~min}$ down to $50^{\circ} \mathrm{C}$, hold time of $23 \mathrm{~min}$ at $50^{\circ} \mathrm{C}$. After digestion the obtained solutions were filtered in $25 \mathrm{~mL}$ Teflon flasks and the rest of the vessel was filled with redistilled water in which chemical analysis was performed.

\section{Instrumentation}

All reagents used in this work were analytical grade or better: nitric acid, trace pure (Merck, Germany) and hydrogen peroxide, p.a. (Merck, Germany). For glassware washing and other tools used for preparation of samples redistilled water was always used, as well as for solutions preparation. Standard solutions of metals were prepared by dilution of $1000 \mathrm{mg} / \mathrm{L}$ solutions (11355-ICP multi Element Standard).

Inductively coupled plasma-atomic emission spectrometry (ICP-AES) was used for the determination of the following elements: Al, $\mathrm{Cr}, \mathrm{Cu}, \mathrm{Fe}, \mathrm{Mn}$, and Zn (Varian, model 715ES). The QC/QA of the applied technique was performed by standard addition method and it was found that the recovery for the investigated elements ranges from $98.5-101.2 \%$. Quality control was also ensured by standard moss reference materials M2 and M3, which are prepared for the European Moss Survey (Steinnes et al. 1997b). The measured concentrations were in good agreement with the recommended values. 
For the determination of $\mathrm{Cd}, \mathrm{Ni}$, and $\mathrm{Pb}$, the isotopes ${ }^{60} \mathrm{Ni},{ }^{114} \mathrm{Cd}$, and ${ }^{206} \mathrm{~Pb},{ }^{207} \mathrm{~Pb}$, ${ }^{208} \mathrm{~Pb}$, inductively coupled plasma - mass spectrometry, ICP-MS (Plasma Quant ICP-MS, Analytic Jena, Germany) was used. External calibration was performed by measuring standard solutions of these elements at $0.5,1,2,5,10$ and $100 \mu \mathrm{g} / \mathrm{L}$ concentrations for following isotopes ${ }^{114} \mathrm{Cd}$, and $\mathrm{Pb}\left({ }^{206} \mathrm{~Pb},{ }^{207} \mathrm{~Pb},{ }^{208} \mathrm{~Pb}\right)$. No internal standards were used. Detector attenuation mode was used to cover wide range of linearity without of collision gas. For the problematic isotopes such as ${ }^{60} \mathrm{Ni}$, He was used as a collision gas. ${ }^{60} \mathrm{Ni}$ was determinate by external calibration in range of 1, 5, 10, 50100 and $500 \mu \mathrm{g} / \mathrm{L}$. The limit of detection and quantification was automatically calculated by the instrument software (Aspect MS 4.3, 2017). Standard solutions were inserted into the sample sequence at every 20 samples to verify sensitivity and repeatability. The recoveries of these elements were $82.1-105.1 \%$.

\section{Statistical analysis}

Distribution maps of elements as well as basic and multivariate statistical analysis was performed on the data obtained from chemical analysis of mosses samples. Statistica 13 software package (StatSoft, Inc., Tulsa, OK, USA), whereas the date visualization was performed by means of several soft-ware packages: Statistica 13 (StatSoft, Inc., Tuls, OK, USA), QGIS and Surfer 17 (Golden Software, Inc., Golden, CO, USA). Some of the basic statistical quantities calculated, were the mean, median, minimum, maximum, tenth percentile, ninetieth percentile, standard deviation, coefficient of variation, standard deviation (standard error), MAD (median absolute deviation), skewness, kurtosis. Pearson correlation coefficients were calculated for all the elements concentration in samples and values 0.30 and higher were considered as significant. In order to reveal the possible polluted sites, principal component analysis was performed and sampling sites ware plotted in two principal components graph.

\section{Pollution indices}

Contamination factor (CF) (Fernández and Carballeira 2001) and pollution load index (PLI) were calculated (Tomlinson et al. 1980), for pollution level evaluation. The formula for calculation of CF used to evaluate the pollution of a single heavy metal in the mosses samples is:

$$
C F=\frac{C_{\text {sample }}^{i}}{C_{\text {reference }}^{i}}
$$

Where CF is the contamination factor for a heavy metal; $C_{\text {sample }}$ is the measured value of the heavy metal in mosses; $C_{\text {reference }}$ the median of the heavy metal in Norway mosses samples in this study. CF values are categorized as follows (Fernández and Carballeira 2001): CF $<1$ - no contamination, $1 \leq \mathrm{CF} \leq 2-$ suspected contamination, $2 \leq \mathrm{CF} \leq 3.5$ - slightly contaminated, and $3.5 \leq \mathrm{CF} \leq 8$ - moderate, $8 \leq \mathrm{CF} \leq 27$ severe, and $\mathrm{CF}>27$ extreme contamination factor.

The pollution load index of one sampling site is calculated as the $n$-th root of the product of $n$ CFs of the metals (Tomlinson et al. 1980): 


\section{$P L I_{\text {site }}=\sqrt[n]{C F_{1} \times C F_{2} \times \ldots C F_{n}}$}

Whereas the PLI of the whole zone (in this case the territory of Kosovo) is calculated according to the formula:

$$
\text { PLI }_{\text {zone }}=\sqrt[n]{\text { site }_{1} x \text { site }_{2} x \ldots \text { site }_{n}}
$$

Where site is sampling site and $n$ is the number of sampling sites. The obtained PLI values are categorized as follows (Zhang et al. 2011): $\mathrm{PLI}=0$ background concentration, $0<\mathrm{PLI} \leq 1$ unpolluted, $1<\mathrm{PLI} \leq 2$ moderately to unpolluted, $2<\mathrm{PLI} \leq 3$ moderately polluted, $3<\mathrm{PLI} \leq 4$ moderately to highly polluted, $4<\mathrm{PLI} \leq 5$ highly polluted, and $\mathrm{PLI}>5$ very highly polluted.

\section{Results And Discussion}

The determination of nine heavy metals was performed in 45 moss samples collected throughout the Kosovo territory. To better present and understand the concentrations which resulted from the chemical analysis, the crude data were processed by statistical methods. In table 1 descriptive statistics quantities are presented. In the table high concentrations of $\mathrm{Al}$ and Fe stand out, which are followed by Mn. High concentrations of these heavy metals are always expected as they are the prevailing heavy metals of earth's crust. $\mathrm{Zn}$ and Pb also occur in high concentrations but less than $\mathrm{Mn}$. The order of median concentration of the analysed metals is, $\mathrm{Al}>\mathrm{Fe}>\mathrm{Mn}>\mathrm{Zn}>\mathrm{Pb}>\mathrm{Cu}>\mathrm{Cr}>\mathrm{Ni}>\mathrm{Cd}$. A striking difference between the maximum concentration and the $90^{\text {th }}$ percentile can be observed for $\mathrm{Ni}$ and $\mathrm{Pb}$. Although the maximum concentrations of these two elements are very high - $79 \mathrm{mg} / \mathrm{kg}$ for $\mathrm{Ni}$ and $38 \mathrm{mg} / \mathrm{kg}$ for $\mathrm{Pb}$ - their $90^{\text {th }}$ percentiles are only $6.1 \mathrm{mg} / \mathrm{kg}$ and $10 \mathrm{mg} / \mathrm{kg}$ correspondingly. A big difference between the maximum concentration of $150 \mathrm{mg} / \mathrm{kg}$ and the $P 9049 \mathrm{mg} / \mathrm{kg}$ was found also for $\mathrm{Zn}$. The big difference between these two statistical quantities, indicates distinguishable zones over the study area with the presence of particular heavy metals, which can also mean presence of pollution. The high values of skewness and kurtosis, indicate that the distribution of concentrations of heavy metals in moss samples is not normal. Except for $\mathrm{Pb}$ and $\mathrm{Ni}$ the concentration distributions of all other heavy metals fit more closely lognormal distribution. $\mathrm{Pb}$ and $\mathrm{Ni}$ have also high coefficient of variation, most probably arising from artificial introduction of these two elements in the environment.

\section{Spatial distribution}

Spatial distribution maps of studied heavy metals are presented in figure 3 . Al and Fe show very similar distribution patterns. Their highest concentrations are found in the east of Kosovo as well as around the centre. Maximum concentration of these two metals is found in Siboc (28) municipality of Obiliq, $2700 \mathrm{mg} / \mathrm{kg}$ for Al and $2000 \mathrm{mg} / \mathrm{kg}$ for Fe. High concentrations of Al and Fe are expected as they are the most abundant metals naturally present in soil, whereby under the effects of wind and precipitation they reach mosses. However the anthropogenic origin cannot be fully excluded (Ötvös et al. 2003). The maximum Fe concentration in the present moss survey $(2000 \mathrm{mg} / \mathrm{kg})$ is lower than that of 2010 survey which was 3082 $\mathrm{mg} / \mathrm{kg}$, but the median is higher, $820 \mathrm{mg} / \mathrm{kg}$ vs $288 \mathrm{mg} / \mathrm{kg}$ (Maxhuni et al. 2016). Noteworthy is the fact that the difference between the present heavy metals concentration in mosses and that of 2010 survey, cannot be taken as completely valid as none of the sampling locations is the same, and the number of sampling points 
is larger in the present study. This should be considered every time the 2010 survey is referred to in this work. As can be seen in the distribution map, the lowest concentration of both elements are mostly found in the south and in the most north of sampling area. Both metals are present mostly in the districts of Prishtina and Gjilani. Geologically they are mainly present in the areas of clastites of Neogene-Paleogene and flysch of Mesozoic, where they occur in fine soil particles owing to rock weathering under atmospheric conditions and geological processes, whereby transferred in moss by wind and precipitations.

Manganese concentrations are also high in all moss samples with a maximum of $360 \mathrm{mg} / \mathrm{kg}$ in Petrovë (12), then Reqan (9) $329 \mathrm{mg} / \mathrm{kg}$ and Zveqan (41) $312 \mathrm{mg} / \mathrm{kg}$. The highest concentrations of Mn lie almost in a diagonal of the Kosovo map from the north to the south. Mn also is a heavy metal with mostly geogenic origin, but according to its distribution map some anthropogenic contribution may be possible, as in the north of Kosovo Trepça mining and Coal powered electricity plant operate. Compared with 2010 survey, Mn concentration in the present survey is slightly higher (Maxhuni et al. 2016). Its concentration is comparable to values found in Albania and North Macedonia 2015 survey (Stafilov et al. 2018; Lazo et al. 2019), and very much smaller than the values found in Norway in 2015 (Steinnes et al. 2016). Prishtina, Prizreni and Mitrovica are the districts where $\mathrm{Mn}$ is present in highest concentrations, whereas according to geological areas it has the highest concentration in deluvium/proluvium of Quaternary period, Magmatic rocks of Paleogene - Neogene, and flysch of Mesozoic era. It can be seen that the highest concentrations of $\mathrm{Mn}$ relate mostly to particular geological formations which are found in the Prizren district, where there are not any heavy industrial sites. This area in the south, lies close to the border with North Macedonia where Mn was also found at high concentration in mosses (Stafilov et al. 2018). High presence of $\mathrm{Mn}$ in the Mitrovica district in Zveqan (41) corresponds to the mining area, but not only, as there is Lupç (37) where its concentration is also high (although lower than in Zveqan). Both, Zveqan and Lupç are found on or very close to Magmatic formations of Neogene-Paleogene and Clastic of Mesozoic. Lupç (37) is a relatively remote area where heavy pollution emissions are not expected - unlike Zveqan is - however Mn concentration in moss is high, probably indicating that $\mathrm{Mn}$ is mostly of geogenic origin even in Zveqan (41).

Zinc, lead, and copper come next as the most concentrated heavy metals in mosses samples in the territory of Kosovo. All of the three are found around the pollution sources, such as lead and zinc Trepça mines and ore processing units, ferro-nickel smelter in Drenas, coal power plant in Obiliq, and cement production plant in Hani i Elezit. Clearly these elements in the just mentioned areas are of anthropogenic origin. $\mathrm{Zn}$ is found at highest concentrations in the north of Kosovo at sampling points Zveqan (41) $86 \mathrm{mg} / \mathrm{kg}$ and Stanterg (42) $146 \mathrm{mg} / \mathrm{kg}$, then in Çikatovë (27) $64 \mathrm{mg} / \mathrm{kg}$ and Shalc (34) $61 \mathrm{mg} / \mathrm{kg}$. All those points in the district of Mitrovica where $\mathrm{Zn}$ concentration is the highest, are shown in figure 3 . The median of $\mathrm{Zn}$ is lower than in the 2010 survey, the maximum is around twice as high. The median and maximum of $\mathrm{Pb}$ is slightly lower than in 2010, whereas the median of $\mathrm{Cu}$ is higher and the maximum lower than in 2010. The median concentration of $\mathrm{Zn}$ and $\mathrm{Pb}$ are higher than in Albania, North Macedonia and Norway, except for $\mathrm{Zn}$ which median is the same as in Norway (Steinnes et al. 2016; Lazo et al. 2018; Stafilov et al. 2018). In the contrary, median concentration of $\mathrm{Cu}$ was lower than in above mentioned countries. The highest concentration of $\mathrm{Zn}$ corresponds with geologic formation of Magmatic rocks of Neogene-Paleogene which are located around the same sampling sites too. Lead is more present in the North, in the South-West, and in the South-East, with concentrations lower than $\mathrm{Zn}$ and more heterogeneously distributed. Districts with the highest concentration 
of $\mathrm{Pb}$ are Mitrovica and Prizren, whereas according to geological composition $\mathrm{Pb}$ reaches the highest concentrations in Magmatic rocks of Paleogene-Neogene. $\mathrm{Pb}$ shows a similar pattern to $\mathrm{Zn}$ because of the Lead/Zinc mines and smelter in Mitrovica which clearly is the main source of these two heavy metals. Relatively high concentrations of $\mathrm{Pb}$ were found in the district of Prizren $(7.9-10.08 \mathrm{mg} / \mathrm{kg})$, despite the fact that there is no industry involving $\mathrm{Pb}$ particularly. In this regard it can be said that, apart from the traffic emissions coming from the roads and the highway, which pass just beside or join in the Prizren city, long range atmospheric transport may also contribute to the overall $\mathrm{Pb}$ concentration in moss samples (Steinnes et al. 1997a; Steinnes 2001). Cu is mostly present From the North to the South in the districts Mitrovica, Prishtina, Prizren, and Gjilan. Its highest concentration is found at sampling site Shalc (34), it is $8 \mathrm{mg} / \mathrm{kg}$. Cu concentrations are lower than those of $\mathrm{Zn}$ and $\mathrm{Pb}$, whereas they are more evenly spread than $\mathrm{Pb}$. The districts with highest concentrations lie on the areas of geologic formations where Cu concentration is also high. Considering the fact that geologic areas where $\mathrm{Cu}$ concentration is higher, do not always correspond with pollution sources, it may be thought that $\mathrm{Cu}$ occurs in mosses due to natural processes. Particularly high concentrations of these heavy metals in the north have been reported also for soil samples (Šajn et al. 2013; Kerolli-Mustafa et al. 2015b; Kastrati et al. 2021), which partly explains their concentration in mosses. Fine dust particles contaminated with heavy metals, can become airborne during dry seasons and spread by wind in larger areas. But emissions during ore processing also can be spread and settle over a vast territory during time under gravity or by precipitations.

Chromium and nickel have a spatial distribution somewhat similar. Their highest concentrations appear in the west, centre and in the east of sampling area. The highest concentrations of $\mathrm{Cr}$ are those in sampling points Prapashticë (30) $10 \mathrm{mg} / \mathrm{kg}$, Reqan (9) $6.6 \mathrm{mg} / \mathrm{kg}$, and Lupç (37) $5.9 \mathrm{mg} / \mathrm{kg}$. Cr and Ni medians are only slightly smaller than the 2010 survey in Kosovo, whereas medians of these two heavy metals are lower than those of Albania and North Macedonia but higher than Norway (always 2015 surveys). Prishtina is the district where $\mathrm{Cr}$ is at highest concentration, followed by Prizreni, and Peja. Geological formations that contain mostly $\mathrm{Cr}$ are clastic sediments of Neogene-Paleogene, whereas it is found at lowest concentrations in carbonate and metamorfic formations of Paleozoic. Ni represents an outstanding peak in sampling point Harilaq (22) $79 \mathrm{mg} / \mathrm{kg}$, then in Llapushnik (21) $19.8 \mathrm{mg} / \mathrm{kg}$, and Çikataovë (27) $11.6 \mathrm{mg} / \mathrm{kg}$. These high concentrations compared to other samples are expected as the three sampling points are located just close by the Ferro-Nickel facilities, and they are as e result of direct pollution. $\mathrm{Ni}$ is most present in samples of the District of Prishtina, whereas Magmatic rocks of Mesozoic are the geologic areas where it is present mostly, with e very high difference compared to other geologic formations. The three sampling points with peak Ni concentration fall also in the areas of Mesozoic rocks, but outstandingly higher concentrations than in other Mesozoic rocks areas indicate the presence of pollution.

Cadmium is the heavy metal with the lowest concentration in mosses samples in the territory of Kosovo. Cd concentrations are the highest in sampling points Stanterg (42) $2 \mathrm{mg} / \mathrm{kg}$ and Zveqan (41) 1.7 $\mathrm{mg} / \mathrm{kg}$, Siboc (28) $1.15 \mathrm{mg} / \mathrm{kg}$, Te Kalaja (25) $1 \mathrm{mg} / \mathrm{kg}$, Kaçanik (6) $0.8 \mathrm{mg} / \mathrm{kg}$. All these sampling points correspond to sites where pollution is expected because of industrial activities. Cd median is greater than that of 2010 survey in Kosovo, as well as it is greater than the medians found in Albania, North Macedonia, and Norway (2015 surveys). Districts with highest concentrations of Cd are Mitrovica and Gjilani, whereas 
according to geological formations it is Magmatic rocks of Paleogene-Neogene the formation with the highest concentration, and Carbonates of Paleozoic come second.

\section{Multivariate analysis}

In order to identify the pollution or geogenic origin of heavy metals studied, multivariate statistical analysis was carried out. In table 2, Pearson correlation coefficients are given for each combination of elements, where six significant correlations can be seen, all with $\mathrm{p}$ value under 0.05 . The strongest correlation was observed for $\mathrm{Al}$ and $\mathrm{Fe}$ with a value of 0.936 , then $\mathrm{Zn}$ and $\mathrm{Cd}$ with a value of 0.856 . Strong correlation coefficients showed the pairs $\mathrm{Fe}-\mathrm{Cr}(0.751)$ and $\mathrm{Al}-\mathrm{Cr}(0.656)$, whereas there was only one moderate correlation $\mathrm{Pb}-\mathrm{Cd}(0.437)$. Other correlations were weak or very weak.

To identify possible patterns of heavy metals distribution in mosses samples, and from it possible polluted areas and pollution sources, principal component analysis (PCA) was performed. The results obtained are shown in figure 4. The PCA analysis produced two main components (PCs), the first PC accounted for $29.75 \%$ of the total variance and the second PC for $26.25 \%$ of it. Sampling sites could be visualized in the plot of scores of PC1 and PC2. In the PCs score plot can be easily noticed the two sampling sites, Zveqan (41) and Stanterg (42), which score highly on PC2 but also considerably on PC1 and Shalc (34) score is relatively high in PC2. This result can be explained by the loading plot of the variables shown just under the samples plot. It can be seen that Zn, Cd, and Pb also load highly on PC2 and to some value on PC1 also, and the direction of the vectors in PCs loading plot are similar as it is the placement of the sampling points Zveqan (41) and Stanerg (42) in the PCs score plot. Similarly can be argued for Shalc (34). The angel between $\mathrm{Zn}, \mathrm{Pb}$, and $\mathrm{Cd}$ vectors is also small, particularly for $\mathrm{Zn}$ and $\mathrm{Cd}$, which indicates a high correlation between these heavy metals. A high correlation of these elements as well as the vectors' directions, show that Stanterg and Zveqan have high scores mostly as a result of these elements' high presence in that area. This is obviously as a consequence of the Trepça mining and ore enrichment processes, as well as mineral tailing dump just in the south of Mitrovica city (Šajn et al. 2013; Kerolli-Mustafa et al. 2015a).

Sampling point Siboc (28) scored highly in both PCs, and Prapashticë (30), Lupç (37), and Reqan (9) scored highly in PC1. The high scores of these sampling sites can be explained by high values of the variables $\mathrm{Al}, \mathrm{Fe}$, and $\mathrm{Cr}$. Although $\mathrm{Al}$ and $\mathrm{Fe}$ are mostly of geogenic origin, their particularly high concentrations in the moss sample of Siboc (28) clearly reveal the atmospheric pollution effect of coal digging and burning in electricity plant in Obiliq. Cr not being a crustal element but however present in this group of elements, also may be an indicator of the pollution effect of electricity plant. Moreover $\mathrm{Cr}$ was found at relatively high concentrations in the fly ash of lignite used to power the electricity plant (Kittner et al. 2018). Harilq (22) scores relatively high in PC1 and PC2 mostly due to high presence of $\mathrm{Ni}$, and it reflects the atmospheric deposition of dust emitted majorly by ferro-nickel mine in Magure which is located just nearby, and probably also the geochemical composition of the surface soil of the area. As can be seen in variables loading plot, $\mathrm{Cu}$, $\mathrm{Mn}$, and Ni do not show a significant correlation between them or to any of the two already discussed groups. The score plot of the sampling points also shows that most of them score around the origin or in the upper left quadrant of the PCs axes, which means that most of the samples are not strongly influenced by the variables under consideration. 


\section{Pollution indices}

To further estimate the atmospheric pollution level, the values of CF and PLI were calculated and are presented in table 3. According to the categorization of the CF values given by Fernandez (Fernández and Carballeira 2001), only Mn CF values fall in the no contamination interval since they never reach 1 . Most of the $\mathrm{CF}$ of $\mathrm{Cu}$ also do not exceed 1 as well as those for $\mathrm{Zn}$, except for $\mathrm{Zn}$ in sampling points Çikatovë (27) with a CF $=2.1$ which corresponds to slightly contaminated, and Zveqan (41) CF = 2.8 and Stanterg (42) CF = 4.7 as moderately contaminated. Ni shows a variable CF values, among those four sampling sites correspond to moderate contamination, two severe and one has extreme contamination factor. Severe CF was found in Llapushnik (21) and Çikatovë (27), whereas extreme CF resulted Harilaq (22). In case of Al and Fe all sampling sites lie on moderate contamination category or lower. Cr has three sampling sites with severe CF and one with extreme contamination. Cd CF values are the highest for 10 moss samples and fall in the extreme contamination category. All moss samples with high CF are located nearby industrial facilities discussed previously, except Kukljan (1) where no industrial activities are performed but also the CF value of this site is in the lower limit of the sever category (8.9). The highest CF appear to be for $\mathrm{Pb}$, the most of the sampling sites fall in the extreme contamination factor with values over 100 , and the rest of samples corresponds to severe contamination category.

The $\mathrm{PLI}_{\text {site }}$ values for nine heavy metals throughout the sampling area, and then only for four of them are shown in figure 6 . When taking all the nine heavy metals in calculation - according to Zhang (Zhang et al. 2011) PLI categorization - none of the moss sampling sites falls in the category unpolluted site (figure 6a). Ten samples fall in the unpolluted to moderately category, 24 of them are moderately polluted, nine are moderately to highly polluted, and two correspond with highly polluted category. The $\mathrm{PLI}_{\text {zone }}$ for the whole territory of Kosovo when all nine elements were included in the calculation was 2.5, which corresponds to the moderately polluted. However when only $\mathrm{Cd}, \mathrm{Cr}, \mathrm{Ni}$, and $\mathrm{Pb}$ were included in PLI calculation three sampling sites were put in category moderately polluted, only one moderate to highly polluted, three highly polluted, and

38 samples corresponded to very highly polluted category (figure $6 \mathrm{~b}$ ). The $\mathrm{PLI}_{\text {zone }}$ of the entire study area now is 5.1 , which is just in the threshold of very highly polluted category.

\section{Conclusion}

The estimation of atmospheric deposition of heavy metals in the territory of Kosovo was performed using mosses as bioindicators. The concentrations measured in mosses samples vary greatly between heavy metals, as well as for the single metals in different sampling sites. Particularly high concentrations of $\mathrm{Zn}$ and $\mathrm{Pb}$ were found around the Trepça mining area around the city of Mitrovica. However both these heavy metals are present in considerably high concentrations in most of the studied area, including areas where no great pollution sources exist. For this reason more studies are required to well establish if long range transport from known pollution sources is the main contributor to the content of these heavy metals in mosses, or if the geochemical composition of the soil is more significant. $\mathrm{Ni}, \mathrm{Cr}$, and $\mathrm{Cd}$ also showed spikes of concentrations around industrial sites. Principal component analysis revealed particularly polluted sites such as: Zveqan (41) Stanterg (42) polluted with Zn, Cd, and Pb. Then Siboc (28), Reqan (9), Prapashticë (30), and Lupç (37), with high contents of $\mathrm{Al}, \mathrm{Fe}$, and $\mathrm{Cr}$, and the rest of the samples which were more similarly affected by the metals 
und consideration. Harilaq (22) was found to be polluted majorly with Ni. Based on distribution maps and the PCA analysis the most significant sources of heavy metal pollution appear to be: Trepça mining and ore processing facilities in Mitrovica, Artana, and Kishnica, then ferronickel smelter in Drenas and mine in Golesh, thermoelectric power plant in Obilq, and cement production plant in Hani i Elezit. Urban areas such as Prishtina city also contribute to pollution from heavy traffic, combustion of coal for house heating and various local businesses.

According to $\mathrm{CF}$ values only $\mathrm{Mn}, \mathrm{Cu}$, and $\mathrm{Zn}$ in most of sampling sites are not present at concentration when contamination is to be considered. All other heavy metals are found at some contamination category. CF shows that $\mathrm{Pb}$ content in mosses not only is at very extreme contamination category, but extremely high compared to the begging limit of this category which is $27 . \mathrm{PLI}_{\text {site }}$ values also in none of the samples correspond to unpolluted category when all the heavy metals are taken in calculation, and its values increase even more when only $\mathrm{Cd}, \mathrm{Cr}, \mathrm{Ni}$, and $\mathrm{Pb}$ are included in calculation. 38 sites of the sampling area fall in the highest category of pollution for these four heavy metals.

\section{Declarations}

\section{Acknowledgement}

We thank the Kosovo Agency for Environment Protection and Afrim Berisha for collaboration during this research project.

Funding: the authors have no relevant financial or non-financial interests to disclose.

Conflicts of interest/Competing interests: the authors have no conflicts of interest to declare that are relevant to the content of this article.

Availability of data and material: all data generated or analysed during this study are included in this published article.

Code availability: not applicable.

Authors' contributions: Conceptualization: [Musaj Paçarizi, Trajče Stafilov], Methodology: [Trajče Stafilov, Musaj Paçarizi, Flamur Sopaj, Krste Tašev]; Formal analysis and investigation: [Flamur Sopaj, Musaj Paçarizi, Robert Šajn]; Writing - original draft preparation: [Flamur Sopaj]; Writing - review and editing: [Trajče Stafilov, Robert Šajn, Musaj Paçarizi].

\section{References}

1. Abuduwailil J, Zhaoyong Z, Fengqing J (2015) Evaluation of the pollution and human health risks posed by heavy metals in the atmospheric dust in Ebinur Basin in Northwest China. Environ Sci Pollut Res 22:14018-14031. https://doi.org/10.1007/s11356-015-4625-1

2. Arditsoglou A, Samara C (2005) Levels of total suspended particulate matter and major trace elements in Kosovo: A source identification and apportionment study. Chemosphere 59:669-678. 
https://doi.org/10.1016/j.chemosphere.2004.10.056

3. Azuma M, Obayashi A, Kondoh M, et al (2000) Removal of cadmium ion by the moss Pohlia flexuosa. Elsevier Masson SAS

4. Barandovski L, Frontasyeva MV., Stafilov T, et al (2015) Multi-element atmospheric deposition in Macedonia studied by the moss biomonitoring technique. Environ Sci Pollut Res 22:16077-16097. https://doi.org/10.1007/s11356-015-4787-x

5. Duce RA, Hoffman GL, Zoller WH (1975) Atmospheric trace metals at remote northern and southern hemisphere sites: Pollution or natural? Science 187:59-61. https://doi.org/10.1126/science.187.4171.59

6. Fernández JA, Carballeira A (2001) Evaluation of contamination, by different elements, in terrestrial mosses. Arch Environ Contam Toxicol 40:461-468. https://doi.org/10.1007/s002440010198

7. Harmens H, Norris DA, Steinnes E, et al (2010) Mosses as biomonitors of atmospheric heavy metal deposition: Spatial patterns and temporal trends in Europe. Environ Pollut 158:3144-3156. https://doi.org/10.1016/j.envpol.2010.06.039

8. Järup L (2003) Hazards of heavy metal contamination. Br Med Bull 68:167-182. https://doi.org/10.1093/bmb/ldg032

9. Kabashi S, Bekteshi S, Jonuzaj A, Zidanšek A (2011) Dynamic modeling of air pollution and acid rain from energy system and transport in Kosovo. Proc 24th Int Conf Effic Cost, Optim Simul Environ Impact Energy Syst ECOS 2011 2012:2803-2823. https://doi.org/10.4236/ojap.2012.13011

10. Kampa M, Castanas E (2008) Human health effects of air pollution. Environ Pollut 151:362-367. https://doi.org/10.1016/j.envpol.2007.06.012

11. Kastrati G, Paçarizi M, Sopaj F, et al (2021) Investigation of concentration and distribution of elements in three environmental compartments in the region of mitrovica, kosovo: Soil, honey and bee pollen. Int $\mathrm{J}$ Environ Res Public Health 18:1-17. https://doi.org/10.3390/ijerph18052269

12. Kelly FJ, Fussell JC (2011) Air pollution and airway disease. Clin Exp Allergy 41:1059-1071. https://doi.org/10.1111/j.1365-2222.2011.03776.x

13. Kerolli-Mustafa M, Ćurković L, Fajković H, Rončević S (2015a) Ecological risk assessment of jarosite waste disposal. Croat Chem Acta. https://doi.org/10.5562/cca2554

14. Kerolli-Mustafa M, Fajković H, Rončević S, Ćurković L (2015b) Assessment of metal risks from different depths of jarosite tailing waste of Trepça Zinc Industry, Kosovo based on BCR procedure. J Geochemical Explor 148:161-168. https://doi.org/10.1016/j.gexplo.2014.09.001

15. Khan A, Khan S, Khan MA, et al (2015) The uptake and bioaccumulation of heavy metals by food plants, their effects on plants nutrients, and associated health risk: a review. Environ Sci Pollut Res 22:1377213799. https://doi.org/10.1007/s11356-015-4881-0

16. Kittner N, Fadadu RP, Buckley HL, et al (2018) Trace Metal Content of Coal Exacerbates Air-PollutionRelated Health Risks: The Case of Lignite Coal in Kosovo. Environ Sci Technol 52:2359-2367. https://doi.org/10.1021/acs.est.7b04254

17. Klavina L, Springe G, Nikolajeva V, et al (2015) Chemical composition analysis, antimicrobial activity and cytotoxicity screening of moss extracts (Moss Phytochemistry). Molecules 20:17221-17243. https://doi.org/10.3390/molecules200917221

Page 12/23 
18. Kord B, Mataji A, Babaie S (2010) Pine (Pinus Eldarica Medw.) needles as indicator for heavy metals pollution. Int J Environ Sci Technol 7:79-84. https://doi.org/10.1007/BF03326119

19. Lantzy RJ, Mackenzie FT (1979) Atmospheric trace metals: global cycles and assessment of man's impact. Geochim Cosmochim Acta 43:511-525. https://doi.org/10.1016/0016-7037(79)90162-5

20. Lazo P, Stafilov T, Qarri F, et al (2019) Spatial distribution and temporal trend of airborne trace metal deposition in Albania studied by moss biomonitoring. Ecol Indic 101:1007-1017. https://doi.org/10.1016/j.ecolind.2018.11.053

21. Lazo P, Steinnes E, Qarri F, et al (2018) Origin and spatial distribution of metals in moss samples in Albania: A hotspot of heavy metal contamination in Europe. Chemosphere 190:337-349. https://doi.org/10.1016/j.chemosphere.2017.09.132

22. Li J shan, Xue Q, Fang L, Poon CS (2017) Characteristics and metal leachability of incinerated sewage sludge ash and air pollution control residues from Hong Kong evaluated by different methods. Waste Manag 64:161-170. https://doi.org/10.1016/j.wasman.2017.03.033

23. Macedo-Miranda G, Avila-Pérez P, Gil-Vargas P, et al (2016) Accumulation of heavy metals in mosses: a biomonitoring study. Springerplus 5:. https://doi.org/10.1186/s40064-016-2524-7

24. MacNee W, Donaldson K (2003) Mechanism of lung injury caused by PM10 and ultrafine particles with special reference to COPD. Eur Respir Journal, Suppl 21:47-51.

https://doi.org/10.1183/09031936.03.00403203

25. Mahapatra B, Dhal NK, Dash AK, et al (2019) Perspective of mitigating atmospheric heavy metal pollution: using mosses as biomonitoring and indicator organism. Environ Sci Pollut Res 26:2962029638. https://doi.org/10.1007/s11356-019-06270-z

26. Mansha M, Ghauri B, Rahman S, Amman A (2012) Characterization and source apportionment of ambient air particulate matter (PM2.5) in Karachi. Sci Total Environ 425:176-183.

https://doi.org/10.1016/j.scitotenv.2011.10.056

27. Maxhuni A, Lazo P, Kane S, et al (2016) First survey of atmospheric heavy metal deposition in Kosovo using moss biomonitoring. Environ Sci Pollut Res 23:744-755. https://doi.org/10.1007/s11356-0155257-1

28. McDonnell TC, Reinds GJ, Wamelink GWW, et al (2020) Threshold effects of air pollution and climate change on understory plant communities at forested sites in the eastern United States. Environ Pollut 262:114351. https://doi.org/10.1016/j.envpol.2020.114351

29. Nriagu JO (1989) A global assessment of natural sources of atmospheric trace metals. Nature 338:4749

30. Ötvös E, Pázmándi T, Tuba Z (2003) First national survey of atmospheric heavy metal deposition in Hungary by the analysis of mosses. Sci Total Environ 309:151-160. https://doi.org/10.1016/S00489697(02)00681-2

31. Pacyna EG, Pacyna JM, Fudala J, et al (2007) Current and future emissions of selected heavy metals to the atmosphere from anthropogenic sources in Europe. Atmos Environ 41:8557-8566.

https://doi.org/10.1016/j.atmosenv.2007.07.040

Page $13 / 23$ 
32. Pandey N, Sharma CP (2002) Effect of heavy metals Co2+, Ni2+ and Cd2+ on growth and metabolism of cabbage. Plant Sci 163:753-758. https://doi.org/10.1016/S0168-9452(02)00210-8

33. Qarri F, Lazo P, Stafilov T, et al (2014) Multi-elements atmospheric deposition study in Albania. Environ Sci Pollut Res 21:2506-2518. https://doi.org/10.1007/s11356-013-2091-1

34. Reis LSL de S, Pardo PE, Camargos AS, Oba E (2010) Mineral element and heavy metal poisoning in animals. J Med Med Sci 1:560-579

35. Ribeiro AG, Downward GS, Freitas CU de, et al (2019) Incidence and mortality for respiratory cancer and traffic-related air pollution in São Paulo, Brazil. Environ Res 170:243-251.

https://doi.org/10.1016/j.envres.2018.12.034

36. Roberts AW, Roberts EM, Haigler CH (2012) Moss cell walls: Structure and biosynthesis. Front Plant Sci 3:1-7. https://doi.org/10.3389/fpls.2012.00166

37. Rocher V, Azimi S, Gasperi J, et al (2004) Hydrocarbons and metals in atmospheric deposition and roof runoff in central Paris. Water Air Soil Pollut 159:67-86.

https://doi.org/10.1023/B:WATE.0000049165.12410.98

38. Romo-Kröger CM, Morales JR, Dinator MI, et al (1994) Heavy metals in the atmosphere coming from a copper smelter in Chile. Atmos Environ 28:705-711. https://doi.org/10.1016/1352-2310(94)90047-7

39. Rühling $\AA$, Tyler G (2004) Changes in the atmospheric deposition of minor and rare elements between 1975 and 2000 in south Sweden, as measured by moss analysis. Environ Pollut 131:417-423. https://doi.org/10.1016/j.envpol.2004.03.005

40. Šajn R, Aliu M, Stafilov T, Alijagić J (2013) Heavy metal contamination of topsoil around a lead and zinc smelter in Kosovska Mitrovica/Mitrovicë, Kosovo/Kosovë. J Geochemical Explor 134:1-16. https://doi.org/10.1016/j.gexplo.2013.06.018

41. Schröder W, Nickel S (2019) Spatial structures of heavy metals and nitrogen accumulation in moss specimens sampled between 1990 and 2015 throughout Germany. Environ Sci Eur 31:1-15. https://doi.org/10.1186/s12302-019-0216-y

42. Shahid M, Dumat C, Khalid S, et al (2017) Foliar heavy metal uptake, toxicity and detoxification in plants: A comparison of foliar and root metal uptake. J Hazard Mater 325:36-58. https://doi.org/10.1016/j.jhazmat.2016.11.063

43. Silva LT, Pinho JL, Nurusman H (2014) Traffic air pollution monitoring based on an air-water pollutants deposition device. Int J Environ Sci Technol 11:2307-2318. https://doi.org/10.1007/s13762-014-0625-9

44. Soltanali S, Shams Hagani Z, Pazouki Yaftabadi M (2008) Economic evaluation for air pollution control technologies selection in power plants processes. Int J Environ Sci Technol 5:555-564. https://doi.org/10.1007/BF03326053

45. Stafilov T, Šajn R, Barandovski L, et al (2018) Moss biomonitoring of atmospheric deposition study of minor and trace elements in Macedonia. Air Qual Atmos Heal 11:137-152. https://doi.org/10.1007/s11869-017-0529-1

46. Steinnes E (2001) Metal contamination of the natural environment in Norway from long range atmospheric transport. Water Air Soil Pollut 1:449-460 
47. Steinnes E, Allen RO, Petersen HM, et al (1997a) Evidence of large scale heavy-metal contamination of natural surface soils in Norway from long-range atmospheric transport. Sci Total Environ 205:255-266. https://doi.org/10.1016/S0048-9697(97)00209-X

48. Steinnes E, Hanssen JE, Rambæk JP, Vogt NSB (1994) Atmospheric deposition of trace elements in Norway: Temporal and spatial trends studied by moss analysis. Water Air Soil Pollut 74:121-140. https://doi.org/10.1007/BF01257151

49. Steinnes E, Rühling $\AA$, Lippo H, Mäkinen A (1997b) Reference materials for large-scale metal deposition surveys. Accredit Qual Assur 2:243-249. https://doi.org/10.1007/s007690050141

50. Steinnes E, Uggerud HT, Pfaffhuber KA, Torunn B (2016) Atmospheric deposition of heavy metals in Norway. 1-57

51. Suvarapu LN, Baek SO (2017) Determination of heavy metals in the ambient atmosphere: A review. Toxicol Ind Health 33:79-96. https://doi.org/10.1177/0748233716654827

52. Thayer JS, Brinckman FE (1982) The Biological Methylation of Metals and Metalloids

53. Thöni L, Yurukova L, Bergamini A, et al (2011) Temporal trends and spatial patterns of heavy metal concentrations in mosses in Bulgaria and Switzerland: 1990-2005. Atmos Environ 45:1899-1912. https://doi.org/10.1016/j.atmosenv.2011.01.039

54. Tomlinson DL, Wilson JG, Harris CR, Jeffrey DW (1980) Problems in the assessment of heavy-metal levels in estuaries and the formation of a pollution index. Helgoländer Meeresuntersuchungen 33:566575. https://doi.org/10.1007/BF02414780

55. Trindade HA, Pfeiffer WC, Londres H, Costa-Ribeiro CL (1981) Atmospheric Concentration of Metals and Total Suspended Particulates in Rio de Janeiro. Environ Sci Technol 15:84-89. https://doi.org/10.1021/es00083a008

56. Vianna NA, Gonçalves D, Brandão F, et al (2011) Assessment of heavy metals in the particulate matter of two Brazilian metropolitan areas by using Tillandsia usneoides as atmospheric biomonitor. Environ Sci Pollut Res 18:416-427. https://doi.org/10.1007/s11356-010-0387-y

57. Walsh PR, Duce RA, Fasching JL (1979) Considerations of the Enrichment, Sources, and Flux of Arsenic in the Troposphere. J Geophys Res 84:1719-1726. https://doi.org/10.1029/jc084ic04p01719

58. Webb AH, Bawden RJ, Busby AK, Hopkins JN (1992) Studies on the effects of air pollution on limestone degradation in Great Britain. Atmos Environ Part B, Urban Atmos 26:165-181.

https://doi.org/10.1016/0957-1272(92)90020-S

59. WELLS JM, BROWN DH (1990) Ionic control of intracellular and extracellular Cd uptake by the moss Rhytidiadelphus squarrosus (Hedw.) Warnst. New Phytol 116:541-553. https://doi.org/10.1111/j.14698137.1990.tb00538.x

60. Xia L, Gao Y (2011) Characterization of trace elements in PM2.5 aerosols in the vicinity of highways in northeast New Jersey in the U.S. East coast. Atmos Pollut Res 2:34-44. https://doi.org/10.5094/APR.2011.005

61. Zechmeister HG (1998) Annual growth of four pleurocarpous moss species and their applicability for biomonitoring heavy metals. Environ Monit Assess 52:441-451.

https://doi.org/10.1023/A:1005843032625

Page 15/23 
62. Zeneli L, Daci N, Paçarizi H, Daci-Ajvazi M (2011) Impact of environmental pollution on human health of the population which lives nearby Kosovo thermopower plants. Indoor Built Environ 20:479-482. https://doi.org/10.1177/1420326X11409471

63. Zhang C, Qiao Q, Piper JDA, Huang B (2011) Assessment of heavy metal pollution from a Fe-smelting plant in urban river sediments using environmental magnetic and geochemical methods. Environ Pollut 159:3057-3070. https://doi.org/10.1016/j.envpol.2011.04.006

64. Zhu Q, Liu Y, Jia R, et al (2018) A numerical simulation study on the impact of smoke aerosols from Russian forest fires on the air pollution over Asia. Atmos Environ 182:263-274. https://doi.org/10.1016/j.atmosenv.2018.03.052

\section{Tables}

Table 1 Descriptive statistic of measurements for moss samples (in $\mathrm{mg} / \mathrm{kg}$ )

\begin{tabular}{|c|c|c|c|c|c|c|c|c|c|c|c|c|}
\hline Element & $x$ & Md & Min & Max & P10 & P90 & $S$ & CV & $s_{x}$ & MAD & $A$ & $E$ \\
\hline $\mathrm{Al}^{\mathrm{a}}$ & 1100 & 890 & 480 & 2700 & 600 & 1900 & 520 & 48 & 77 & 230 & 1.32 & 1.26 \\
\hline$C d^{b}$ & 0.48 & 0.36 & 0.16 & 2.1 & 0.23 & 0.80 & 0.38 & 78 & 0.056 & 0.11 & 2.59 & 7.69 \\
\hline $\mathrm{Cr}^{\mathrm{a}}$ & 3.1 & 2.6 & 0.93 & 10.1 & 1.5 & 5.5 & 1.8 & 58 & 0.27 & 1.0 & 1.64 & 3.90 \\
\hline $\mathrm{Cu}^{\mathrm{a}}$ & 3.9 & 3.9 & 2.6 & 8.1 & 2.9 & 4.6 & 0.94 & 24 & 0.14 & 0.52 & 2.14 & 8.00 \\
\hline $\mathrm{Fe}^{\mathrm{a}}$ & 920 & 820 & 430 & 2000 & 530 & 1400 & 390 & 42 & 58 & 200 & 1.09 & 0.47 \\
\hline $\mathrm{Mn}^{\mathrm{a}}$ & 110 & 88 & 41 & 360 & 50 & 210 & 74 & 67 & 11 & 28 & 2.01 & 3.98 \\
\hline $\mathrm{Ni}^{\mathrm{b}}$ & 4.4 & 1.7 & 0.46 & 79 & 0.82 & 6.1 & 12 & 270 & 1.8 & 0.75 & 5.98 & 37.83 \\
\hline $\mathrm{Pb}^{\mathrm{b}}$ & 6.6 & 7.3 & 0.58 & 38 & 0.63 & 10 & 6.0 & 90 & 0.89 & 2.5 & 3.24 & 16.78 \\
\hline$Z n^{a}$ & 36 & 31 & 20 & 150 & 23 & 49 & 21 & 58 & 3.1 & 5.2 & 3.97 & 18.82 \\
\hline
\end{tabular}

$\mathrm{X}$ - arithmetical mean, Md - median, Min - minimum, Max - maximum, P10 - 10 percentile, P90 - 90 percentile, $\mathrm{S}$ - standard deviation, $\mathrm{S}_{\mathrm{X}}$ - standard error of mean, CV - coefficient of variation, MAD -median absolute deviation, A -skewness, E - kurtosis, a - Determined by ICP-AES, b - Determined by ICP-MS. 
Table 2 Pearson correlation coefficients between element concentrations in mosses in Kosovo

\begin{tabular}{clllllllll}
\hline Elements & $\mathrm{Al}$ & $\mathrm{Cd}$ & $\mathrm{Cr}$ & $\mathrm{Cu}$ & $\mathrm{Fe}$ & $\mathrm{Mn}$ & $\mathrm{Ni}$ & $\mathrm{Pb}$ & $\mathrm{Zn}$ \\
\hline $\mathrm{Al}$ & 1.000 & & & & & & & & \\
$\mathrm{Cd}$ & -0.068 & 1.000 & & & & & & & \\
$\mathrm{Cr}$ & 0.656 & -0.146 & 1.000 & & & & & & \\
$\mathrm{Cu}$ & 0.035 & 0.173 & 0.027 & 1.000 & & & & & \\
$\mathrm{Fe}$ & 0.936 & -0.094 & 0.751 & 0.037 & 1.000 & & & & \\
$\mathrm{Mn}$ & 0.206 & 0.265 & 0.064 & 0.228 & 0.193 & 1.000 & & & \\
$\mathrm{Ni}$ & -0.059 & -0.086 & 0.193 & -0.155 & 0.203 & -0.089 & 1.000 & & \\
$\mathrm{~Pb}$ & 0.069 & 0.437 & -0.092 & 0.037 & 0.018 & 0.242 & -0.174 & 1.000 & \\
$\mathrm{Zn}$ & -0.075 & 0.858 & -0.069 & 0.213 & -0.048 & 0.226 & -0.035 & 0.351 & 1.000 \\
\hline
\end{tabular}


Table 3 Contamination factor (CF) values for heavy metals measured in 45 moss samples (in $\mathrm{mg} / \mathrm{kg}$ )

\begin{tabular}{|c|c|c|c|c|c|c|c|c|c|}
\hline Sample site & $\mathrm{Al}$ & $\mathrm{Cd}$ & $\mathrm{Cr}$ & $\mathrm{Cu}$ & $\mathrm{Fe}$ & $\mathrm{Mn}$ & $\mathrm{Ni}$ & $\mathrm{Pb}$ & $\mathrm{Zn}$ \\
\hline 1 & 1.5 & 8.9 & 3.1 & 1.1 & 1.9 & 0.4 & 1.1 & 158.0 & 0.9 \\
\hline 2 & 1.7 & 3.9 & 3.3 & 1.1 & 2.1 & 0.1 & 1.0 & 179.0 & 0.9 \\
\hline 3 & 1.0 & 4.5 & 2.2 & 0.9 & 1.4 & 0.3 & 0.7 & 180.7 & 1.1 \\
\hline 4 & 1.2 & 8.9 & 1.3 & 1.0 & 1.5 & 0.2 & 0.4 & 11.9 & 0.9 \\
\hline 5 & 3.1 & 7.7 & 4.0 & 0.8 & 3.5 & 0.1 & 1.0 & 206.6 & 0.7 \\
\hline 6 & 2.5 & 10.0 & 4.0 & 1.0 & 3.0 & 0.1 & 0.8 & 145.9 & 0.9 \\
\hline 7 & 1.7 & 5.1 & 5.1 & 0.6 & 2.3 & 0.2 & 4.9 & 201.7 & 1.1 \\
\hline 8 & 3.3 & 3.4 & 6.1 & 1.0 & 3.5 & 0.1 & 1.5 & 196.2 & 0.9 \\
\hline 9 & 4.0 & 4.9 & 9.4 & 1.1 & 4.6 & 0.8 & 2.8 & 25.5 & 0.9 \\
\hline 10 & 2.8 & 4.0 & 3.2 & 1.1 & 3.6 & 0.4 & 1.0 & 173.7 & 1.1 \\
\hline 11 & 1.3 & 2.9 & 1.8 & 0.8 & 1.9 & 0.2 & 0.7 & 139.2 & 0.8 \\
\hline 12 & 2.6 & 5.9 & 2.1 & 0.8 & 2.9 & 0.9 & 3.3 & 58.6 & 0.9 \\
\hline 13 & 1.3 & 2.8 & 7.3 & 0.7 & 2.2 & 0.2 & 7.2 & 11.8 & 0.7 \\
\hline 14 & 1.8 & 2.9 & 4.9 & 0.7 & 2.7 & 0.1 & 5.5 & 192.6 & 0.8 \\
\hline 15 & 1.5 & 3.6 & 2.6 & 0.9 & 1.9 & 0.2 & 1.0 & 170.7 & 0.9 \\
\hline 16 & 1.6 & 5.1 & 2.6 & 0.7 & 2.1 & 0.2 & 1.0 & 185.1 & 0.7 \\
\hline 17 & 3.2 & 3.3 & 5.0 & 0.9 & 4.4 & 0.2 & 0.8 & 137.1 & 0.8 \\
\hline 18 & 2.0 & 4.5 & 4.8 & 0.8 & 2.8 & 0.2 & 3.4 & 147.6 & 0.8 \\
\hline 19 & 2.1 & 5.6 & 3.8 & 0.9 & 2.5 & 0.6 & 2.3 & 12.5 & 0.9 \\
\hline 20 & 1.6 & 3.7 & 2.9 & 0.7 & 2.0 & 0.1 & 1.5 & 166.1 & 1.0 \\
\hline 21 & 1.5 & 4.6 & 6.8 & 1.1 & 2.6 & 0.2 & 18.0 & 33.6 & 1.0 \\
\hline 22 & 2.0 & 4.0 & 5.7 & 0.7 & 4.5 & 0.2 & 72.2 & 36.3 & 1.0 \\
\hline 23 & 2.6 & 3.9 & 5.1 & 1.0 & 3.2 & 0.3 & 1.8 & 75.6 & 1.3 \\
\hline 24 & 4.1 & 4.8 & 6.2 & 0.9 & 5.2 & 0.3 & 1.8 & 181.4 & 1.2 \\
\hline 25 & 1.3 & 12.3 & 1.7 & 1.0 & 1.7 & 0.2 & 0.5 & 45.8 & 1.3 \\
\hline 26 & 1.9 & 5.9 & 3.0 & 0.9 & 2.7 & 0.2 & 2.7 & 54.3 & 1.2 \\
\hline 27 & 2.4 & 9.6 & 8.5 & 1.1 & 4.0 & 0.3 & 10.5 & 53.0 & 2.1 \\
\hline 28 & 6.0 & 14.4 & 7.9 & 1.1 & 6.5 & 0.4 & 2.1 & 249.5 & 1.6 \\
\hline 29 & 1.5 & 2.0 & 2.8 & 0.9 & 2.2 & 0.2 & 1.1 & 11.6 & 0.8 \\
\hline 30 & 4.5 & 5.2 & 14.4 & 0.8 & 5.6 & 0.2 & 3.6 & 150.0 & 1.1 \\
\hline 31 & 1.9 & 2.2 & 2.8 & 0.9 & 2.6 & 0.2 & 1.1 & 12.0 & 0.8 \\
\hline 32 & 1.9 & 3.2 & 2.6 & 0.8 & 2.1 & 0.2 & 0.8 & 12.9 & 0.8 \\
\hline 33 & 3.6 & 2.8 & 6.7 & 0.8 & 3.6 & 0.1 & 1.7 & 111.2 & 0.7 \\
\hline 34 & 1.9 & 10.0 & 5.4 & 1.9 & 2.9 & 0.2 & 2.2 & 87.5 & 2.0 \\
\hline 35 & 4.5 & 3.1 & 4.8 & 0.8 & 4.7 & 0.2 & 1.3 & 183.5 & 0.9 \\
\hline 36 & 2.3 & 3.4 & 2.3 & 0.8 & 2.8 & 0.3 & 0.7 & 138.3 & 0.8 \\
\hline 37 & 4.1 & 2.1 & 8.4 & 0.8 & 5.8 & 0.5 & 2.6 & 147.4 & 1.0 \\
\hline 38 & 3.9 & 3.0 & 4.8 & 1.1 & 4.6 & 0.3 & 1.7 & 152.9 & 1.2 \\
\hline 39 & 1.7 & 8.8 & 2.5 & 0.9 & 2.2 & 0.2 & 1.1 & 27.2 & 1.4 \\
\hline 40 & 1.2 & 3.2 & 2.1 & 0.8 & 1.6 & 0.1 & 2.9 & 161.6 & 1.1 \\
\hline 41 & 1.4 & 20.9 & 2.1 & 1.0 & 2.0 & 0.8 & 0.9 & 760.3 & 2.8 \\
\hline 42 & 1.6 & 25.7 & 2.3 & 0.8 & 2.0 & 0.3 & 1.1 & 177.8 & 4.7 \\
\hline 43 & 1.2 & 6.0 & 2.2 & 1.4 & 1.7 & 0.4 & 0.9 & 245.5 & 1.3 \\
\hline 44 & 1.8 & 3.4 & 5.3 & 0.6 & 2.4 & 0.2 & 2.5 & 141.4 & 1.0 \\
\hline 45 & 1.8 & 4.9 & 3.2 & 1.0 & 2.4 & 0.3 & 1.4 & 31.8 & 1.2 \\
\hline
\end{tabular}

Figures 


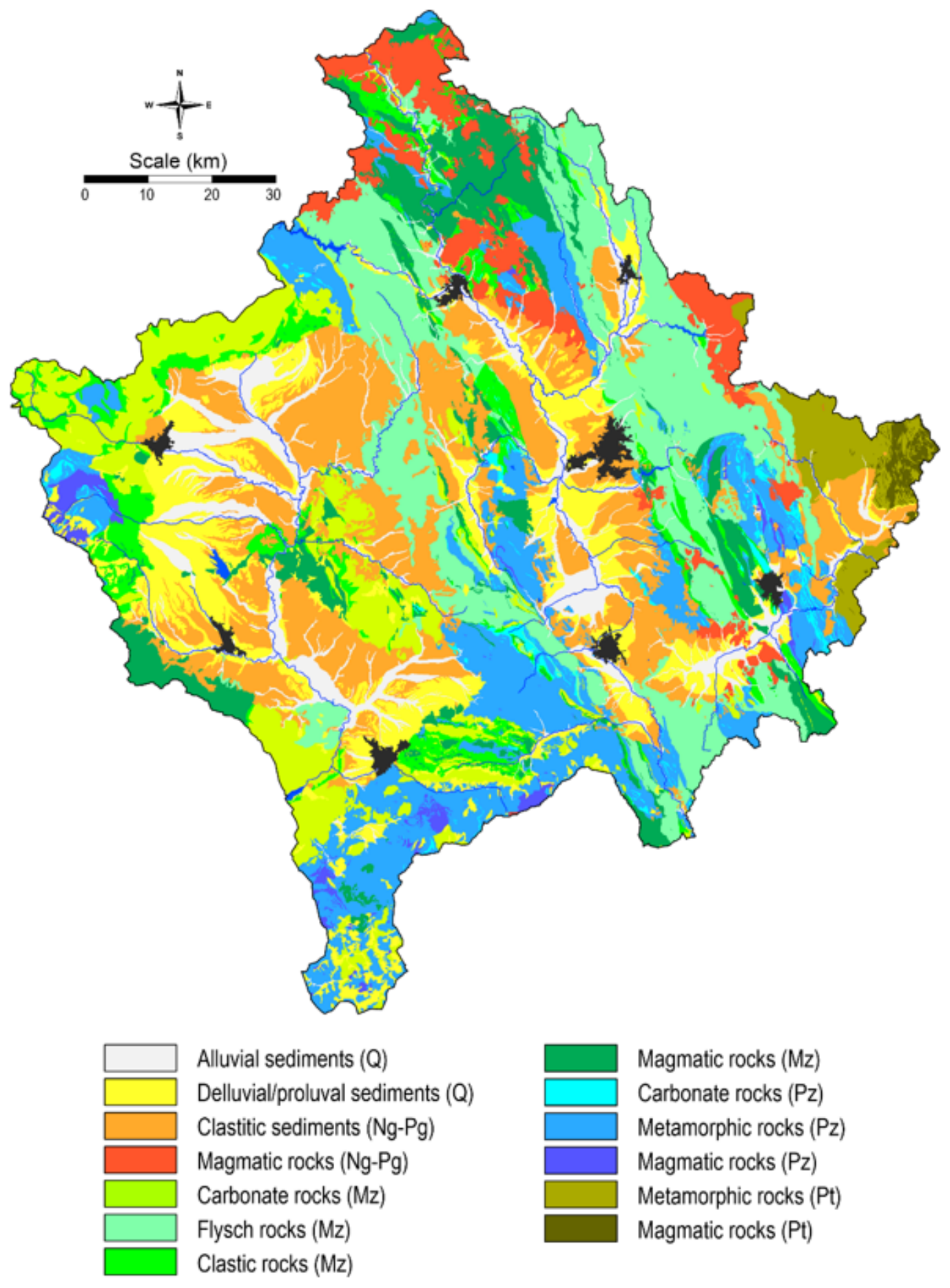

Figure 1

Map of the geological formations of Kosovo 


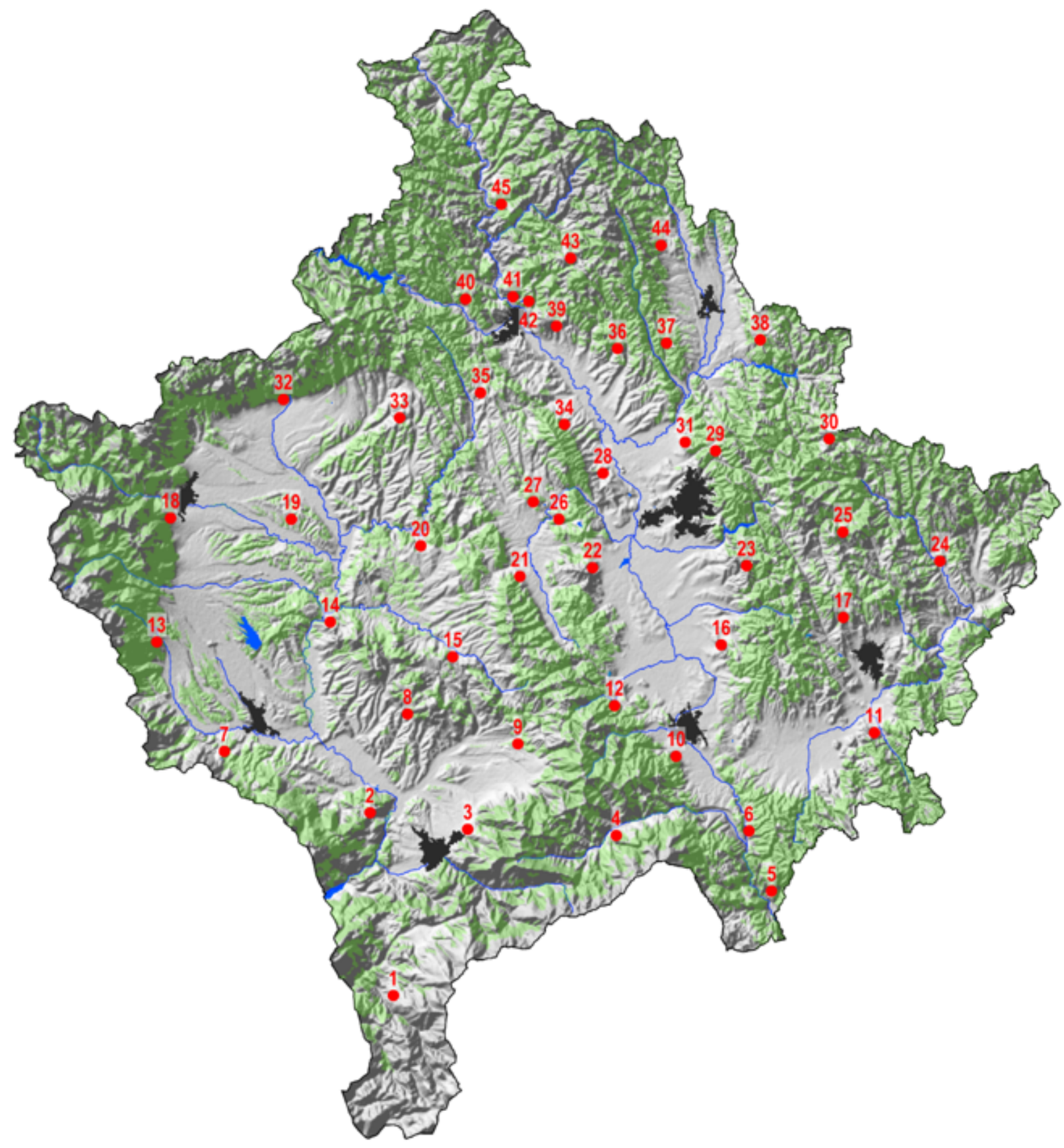

Figure 2

Map of the distribution of sampling points of mosses 

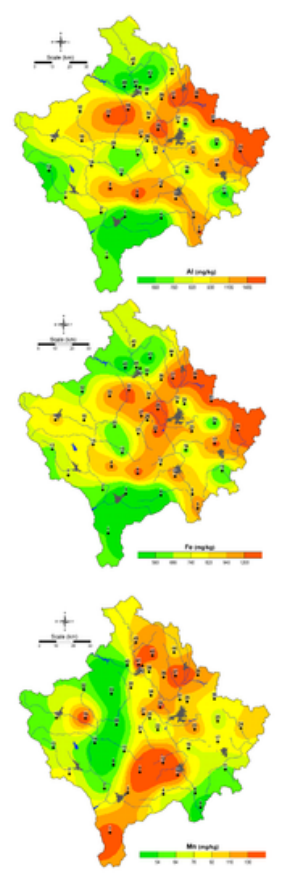
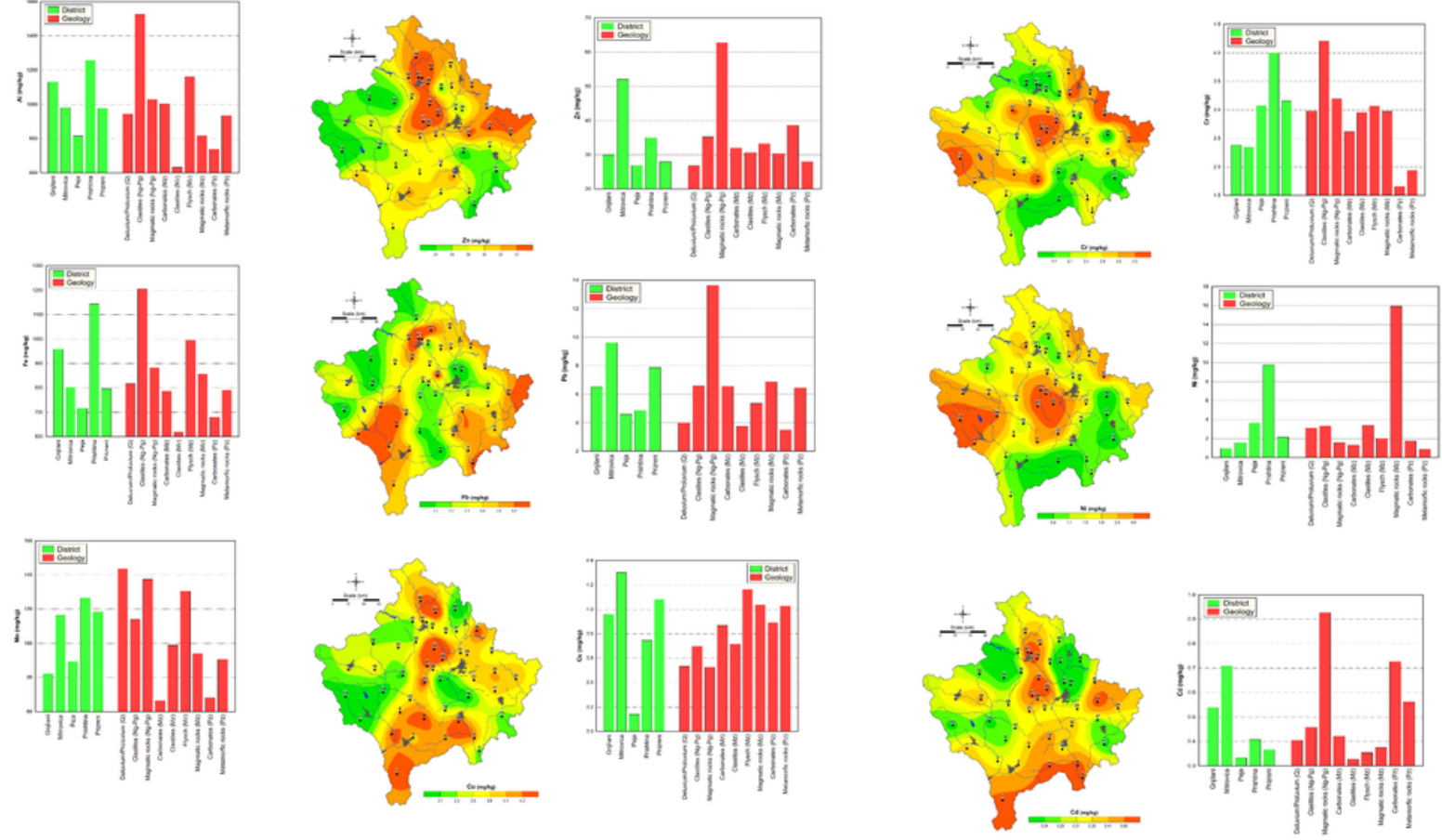

Figure 3

Distribution of the concentration of heavy metals in $\mathrm{mg} / \mathrm{kg}$ in the study area 

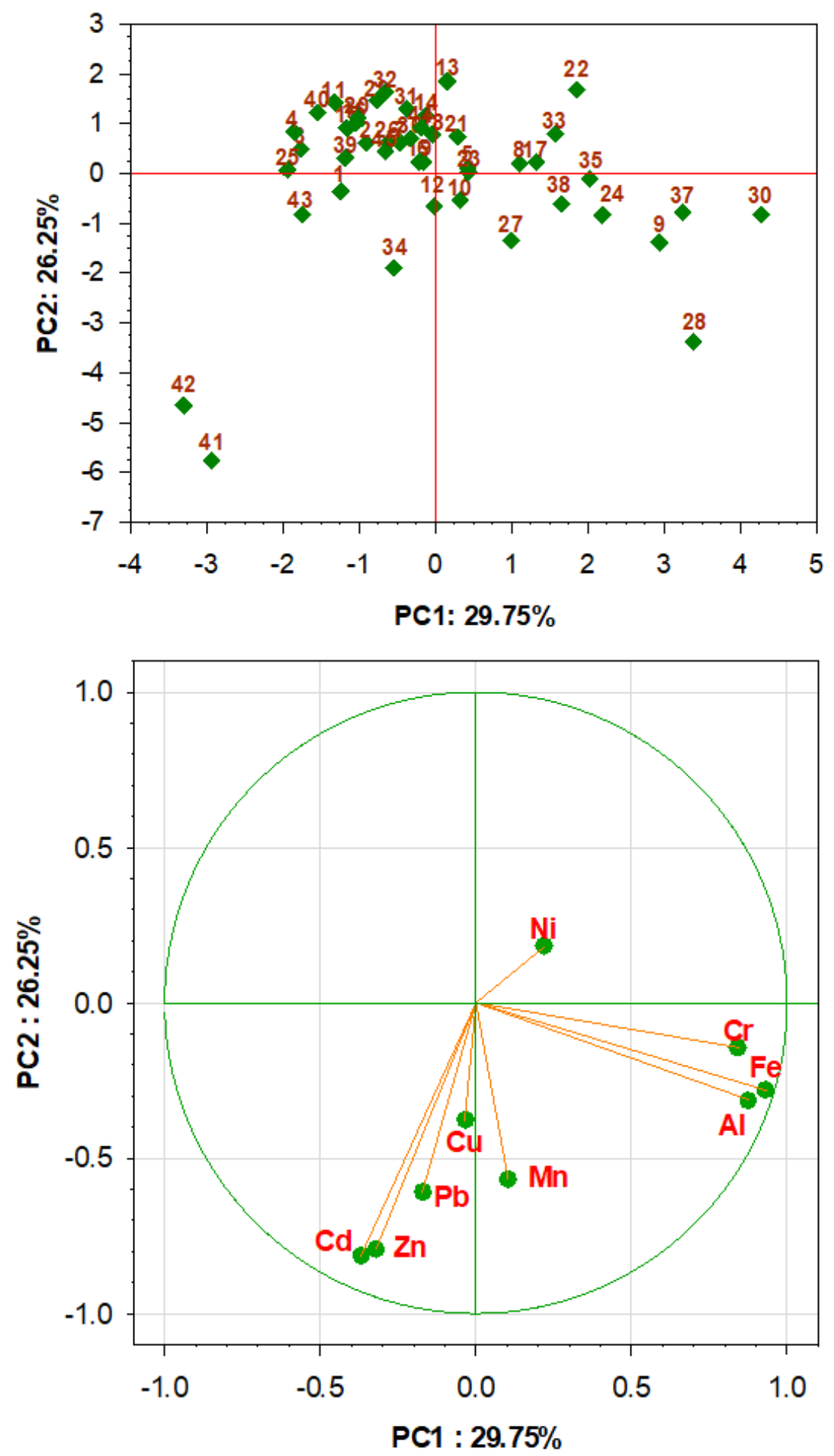

Figure 4

Multivariate principal component analysis of nine heavy metals for 45 moss sampling sites 


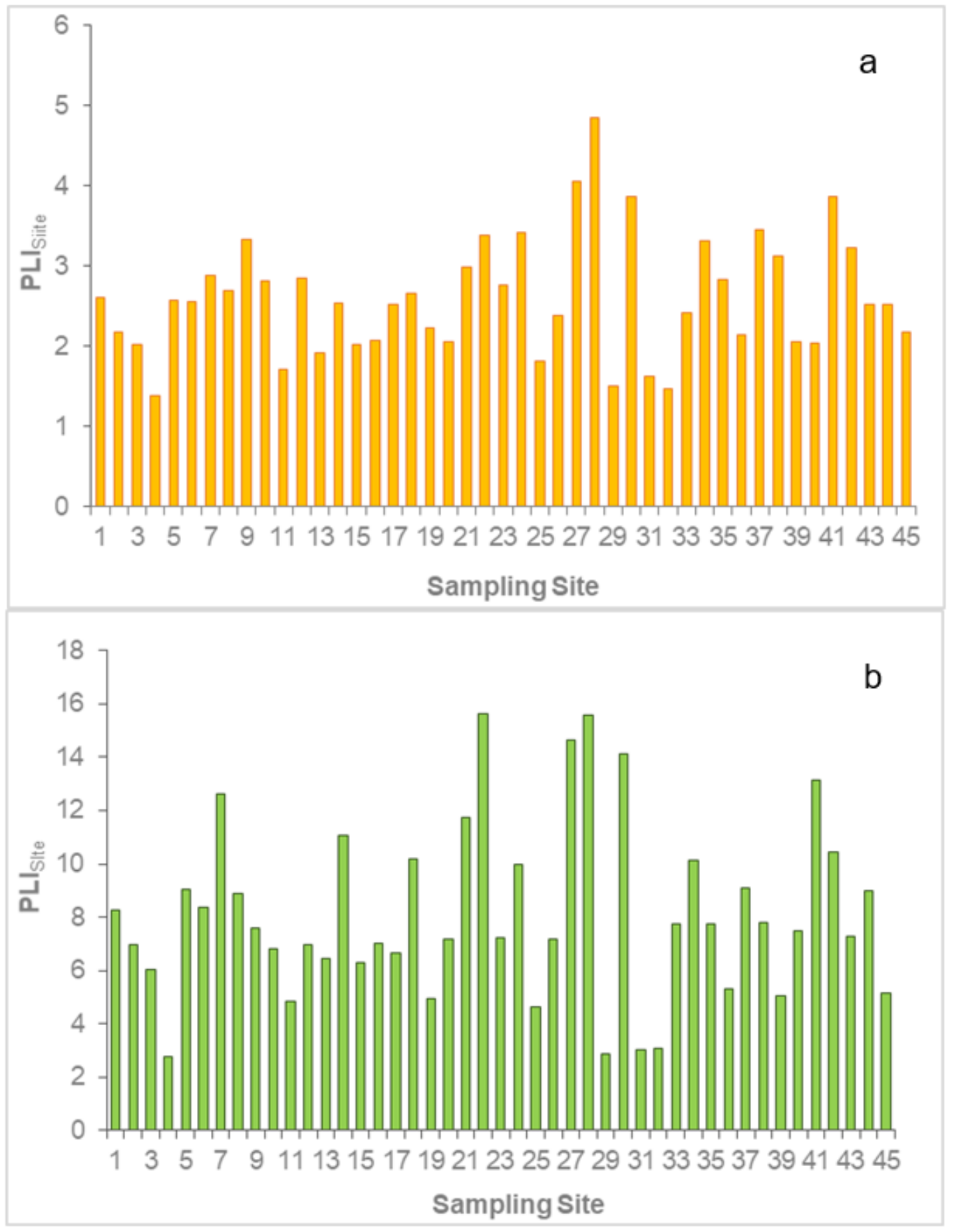

Figure 5

Pollution load index calculated for nine heavy metals a), and b) for $\mathrm{Cd}, \mathrm{Cr}, \mathrm{Ni}$, and $\mathrm{Pb}$ 